\title{
ZAWODNOŚCI RYNKÓW I PAŃSTWA W HISTORYCZNEJ ANALIZIE INSTYTUCJONALNEJ DOUGLASSA C. NORTHA I AVNERA GREIFA
}

\section{WSTĘP}

Od kiedy powstały i rozpowszechniły się pojęcia zawodności rynków i państwa (market and government failures), a nawet przed ich pojawieniem się, ekonomiści zajmowali się dobrami publicznymi, asymetrią informacji czy poszukiwaniem renty (rent-seeking). W zdecydowanej większości były to jednak opracowania ściśle teoretyczne. A przecież rynki, państwo oraz wskaźniki efektywności ich funkcjonowania są zjawiskami empirycznymi o charakterze historycznym. Relacje ekonomii i historii gospodarczej są trudne i złożone ${ }^{1}$, lecz potencjalna wartość historii gospodarczej dla ekonomistów raczej nie wywołuje kontrowersji: jeśli ekonomia mieni się nauką empiryczną o procesie gospodarowania, to konfrontacja z systematycznymi opisami wydarzeń gospodarczych z przeszłości może być dla niej nieocenionym probierzem wartości twierdzeń. Na tym większą uwagę zasługują ci historycy, którzy sami próbują stosować teorię ekonomii w wyjaśnianiu gospodarczych dziejów ludzkości.

Do takich historyków zalicza się przede wszystkim Douglassa C. Northa, którego poglądy będą stanowić główną tematykę artykułu, oraz Avnera Greifa. Celem historii gospodarczej w ujęciu Northa jest „wyjaśnienie struktury i efektywności gospodarek w czasie”. Do „struktury” autor ten zalicza „instytucje polityczne i ekonomiczne, technologię, demografię i ideologię społeczeństwa”, a „wyjaśnienie” oznacza dla niego „wyraźnie formułowane teorie potencjalnie możliwe do obalenia"2. Ostatecznym celem współpracy ekonomii i historii gospodarczej

${ }^{1}$ Zob. N. F. R. Crafts, Economic history, [w:] The New Palgrave. A Dictionary of Economics, vol. 2, red. J. Eatwell, M. Milgate, P. Newman, Macmillan, London 1987, s. 37-42.

2 D. C. North, Structure and Change in Economic History, Norton, New York-London 1981, s. 3. 
powinno, według Northa, być dostarczenie rekomendacji i wskazówek politykom (policy-makers), których zadaniem jest właśnie tworzenie ram instytucjonalnych efektywnych rynków i państw, szczególnie w krajach transformacji postsocjalistycznej oraz rozwijających się. Ażeby takich wskazówek udzielać, należy najpierw zrozumieć, jak powstały istniejące systemy instytucji gospodarki rynkowej. To bowiem pojawienie się względnie efektywnych rynków i państw, wyjątkowe w dziejach świata, autor ten uważa za główną przyczynę powstania równie wyjątkowych w czasie i przestrzeni, nowoczesnych gospodarek „świata Zachodu” ( Western world).

Pomimo jasno dostrzeganych wad myślenia neoklasycznego, North i Greif nie przechodzą do heterodoksyjnych kierunków ekonomii, które mogłyby wydawać się naturalnym wyborem przy próbach wyjaśniania historycznej dynamiki instytucjonalnej - do szkoły historycznej lub starego instytucjonalizmu. Zgodnie z sięgającą Johna Stuarta Milla logiką rozważań, North widzi konieczność wyszczególnienia założeń dotyczących zachowań jednostki, z których wynikać będą determinanty warunków wymiany i instytucji. „Przywołujemy w tym celu - pisze - indywidualistyczny postulat maksymalizacyjny teorii ekonomii. Postulat ten zakłada, że jednostki w przypadku braku ograniczeń maksymalizują na wszelkie sposoby (oryg.: at any and all margins)"3. Obaj omawiani autorzy konsekwentnie pozostają w neoklasycznym nurcie wyjaśniania ludzkich wyborów, poszerzanym jedynie w miarę potrzeby o: teorię praw własności A. Alchiana i H. Demsetza, teorię kosztów transakcyjnych O. Williamsona, teorię kontraktów niekompletnych, teorię wyboru publicznego J. M. Buchanana i G. Tullocka, później również o teorię działań zbiorowych M. Olsona, a także elementy psychologii ekonomicznej i behawioralnej teorii gier.

Zastosowanie przez historyków gospodarczych - Northa, a później Greifa głównych elementów nowej ekonomii instytucjonalnej i teorii gier do analizy tradycyjnie teoretycznych problemów zawodności rynków i państwa zaowocowało ciekawymi i ważnymi spostrzeżeniami, których przegląd i uporządkowanie jest celem niniejszego artykułu. Najpierw przedstawiona zostanie przeprowadzona przez Northa krytyka neoklasycznych teorii funkcjonowania i zawodności rynków i państwa. Następnie zreferowane zostanie historyczno-instytucjonalne ujęcie tej problematyki wykorzystywane w pracach obu omawianych autorów ${ }^{4}$. W zakończeniu podjęta zostanie próba podsumowania omówionych poglądów i wyciąnięcia wniosków.

${ }^{3}$ Ibidem, s. 202-203.

${ }^{4}$ Niniejsza prezentacja właściwie pomija wydaną w 2009 r. wspólnie z J. J. Wallisem i B. R. Weingastem pracę D. C. Northa Violence and Social Orders. Za takim rozwiązaniem przemawia względna nowość i odrębność budowanej w tej publikacji wizji nauk społecznych i argumentacji, zasługujących na zupełnie osobne opracowania. 


\section{KRYTYKA GŁÓWNEGO NURTU ANALIZ ZAWODNOŚCI RYNKUI PAŃSTWA}

W ekonomii modelowo-dedukcyjnej dokonuje się uproszczeń elementów rzeczywistości gospodarczej w celu ułatwienia analizy ich najistotniejszych merytorycznie aspektów. Łatwo jednak, konstruując abstrakcje, przedkładać wygodę analizy ponad merytoryczną trafność modelu. Tak też najwyraźniej się stało, kiedy za punkt wyjścia analiz efektywności rynku przyjęto model najprostszy - rynek funkcjonujący „doskonale”. W „domyślnym” modelu doskonale funkcjonującego rynku uwzględniano następnie „błędy” i „zawodności”. Podobnie postąpiono i z państwem, które z początku uznano w ekonomii dobrobytu za „niezawodny” mechanizm korygujący błędy rynku.

Tymczasem, jak zwracają uwagę historycy gospodarczy, przez większość swoich dziejów ludzkość nie umiała ciągnąć pożytków z podziału pracy, konkurencyjne rynki pojawiły się stosunkowo niedawno, państwa i gospodarki po okresach rozwoju i rozkwitu doświadczały prędzej czy później schyłku i upadku, a ludzie żyli w warunkach niepokoju i nędzy. Przy braku instytucji politycznych i ekonomicznych zapewniających bezpieczeństwo gromadzenia majątku i wymiany, życie zdecydowanej większości ludzi, zgodnie z przewidywaniami ekonomii instytucjonalnej i słynnym sformułowaniem Hobbesa, „charakteryzowało się powszechną i wielką niepewnością"5 wynikającą z możliwości nabywania dóbr poprzez przemoc, a zatem rzeczywiście było „nędzne, brutalne i krótkie”. To raczej powstanie „świata Zachodu” - świata rewolucji przemysłowej i nowoczesności, efektywnych rynków i państw oraz niespotykanej gdzie indziej zamożności i bezpieczeństwa - stanowi w historii świata „zjawisko nowe i wyjątkowe” - pewną wręcz zagadkę, niezauważoną jednak, a tym bardziej niewyjaśnioną przez główny nurt ekonomii. $\mathrm{Z}$ perspektywy historii gospodarczej, to nie powstanie „błędów” efektywnego rynku i państwa, lecz same efektywne rynki i państwa są niewiadomą, która w pierwszej kolejności domaga się wyjaśnienia. Co więcej, jak wynikać ma z rozważań Northa m.in. na temat zjawiska zależności od ścieżki (path dependence) ${ }^{7}$, szczególne znaczenie dla efektywności konkretnych rynków i państw ma historyczny przebieg procesu ich kształtowania się, którym to procesem ekonomia głównego nurtu właśnie w ogóle się nie zajmuje. North nazwie „neoklasyczną fikcją” sposób

${ }^{5}$ B. Fiedor, Neoklasyczna teoria instytucji, [w:] Kierunki rozwoju wspótczesnej ekonomii, red. B. Fiedor, Wyd. AE we Wrocławiu, Wrocław 1991, s. 184.

${ }^{6}$ D. C. North, R. P. Thomas, The Rise of the Western World, Cambridge University Press, Cambridge 1973, s. 1.

${ }^{7}$ D. C. North, Institutions, Institutional Change and Economic Performance, Cambridge University Press, Cambridge 1990, rozdział 11: The path of institutional change. 
myślenia o rynkach, że „są” - poprzedzając państwo, a następnie państwo na nich „interweniuje".

Przyczyny braku neoklasycznej teorii długookresowej ewolucji instytucjonalnej tkwią zdaniem Northa głęboko w logice ekonomii głównego nurtu, z założenia statycznej i nieuwzględniającej kosztów transakcyjnych oraz wynikającej $\mathrm{z}$ nich roli instytucji oraz państwa w gospodarce rynkowej. „Po prostu - pisze omawiany autor - ekonomia neoklasyczna jest nieodpowiednim narzędziem analizy i projektowania polityki pobudzającej rozwój”. „W Walrasowskim systemie równowagi ogólnej - wyjaśnia North w innym miejscu - nie ma kosztów wymiany, nie ma państwa, nie ma jakiejkolwiek instytucji poza doskonałym (i darmowym) rynkiem"10. Teoria tak skonstruowana, jeżeli próbować zastosować ją do analizy efektywności gospodarczej w czasie, nie może dać zadowalających rezultatów, opiera się bowiem na dwu kluczowo błędnych założeniach: „że instytucje nie mają znaczenia, i że czas nie ma znaczenia"11. Determinanty kształtowania się efektywności rynku i państwa - historyczny proces kształtowania się konkretnych instytucji - w ogóle nie jest analizowany. Na dodatek, jak zauważył O. E. Williamson, jeżeli założy się brak oportunizmu u aktorów społecznych, ogromnie upraszcza to problemy projektowania instytucji, usuwając z pola widzenia wszystkie trudne problemy zawierania i zabezpieczania (governance) kontraktów, a w konsekwencji prowadząc do utopijnych projektów organizacji gospodarczej społeczeństwa ${ }^{12}$.

Pomimo powyższej krytyki oraz sięgania po coraz dalej idące komplikacje i uzupełnienia, historia gospodarcza Douglassa C. Northa oraz prace Avnera Greifa pozostają neoklasyczną teorią instytucji, mieszczącą się w głównym nurcie ekonomii. Metodologiczny indywidualizm i założenie o maksymalizacji subiektywnie pojmowanego interesu własnego, a także teoria gier, są narzędziami, z których historycy ci, wyjaśniając procesy ekonomiczno-instytucjonalne, nigdy nie zrezygnowali. Przeciwnie, odwołując się do tych właśnie pryncypiów teorii ekonomii, North wychwycił w głównym nurcie myślenia ekonomicznego o efektywności rynku i państwa daleko idącą nieścisłość. Nie wyciąga się w niej mianowicie konsekwentnych wniosków z założenia o maksymalizacji. Jeśli ludzie mak-

${ }^{8}$ Por. D. C. North, J. J. Wallis, B. R. Weingast, A Conceptual Framework for Interpreting Recorded Human History, NBER Working Paper 12795, http://www.nber.org/papers/w12795, December 2006, s. 71.

${ }^{9}$ D. C. North, Efektywność gospodarcza w czasie, [w:] Wspótczesne teorie socjologiczne, t. 1, red. A. Jasińska-Kania, L. M. Nijakowski, J. Szacki, M. Ziółkowski, Scholar, Warszawa 2006, s. 553.

${ }^{10}$ Idem, Government and the Cost of Exchange in History, „Journal of Economic History” 1984, vol. 44 , no. 2 , s. 255 .

${ }^{11}$ Idem, Efektywnośc gospodarcza..., s. 553.

12 O. E. Williamson, Opportunism and its Critics, „Managerial and Decision Economics” 1993, vol. 14, s. 97-107. 
symalizują na wszelkie sposoby, to czy może dziwić, że bywają pasażerami na gapę (free-riders), że maksymalizują quasi-rentę $\mathrm{z}$ asymetrii informacyjnej oraz poszukują renty za pomocą mechanizmów politycznych? W jakim sensie można mówić o „zawodnościach” lub „niedoskonałościach” rynku lub państwa, skoro zachowania te wynikają z najzupełniej prawidłowego rachunku prywatnych korzyści i kosztów, stanowiącego serce modelowego podmiotu ekonomicznego? Jeżeli ludzie maksymalizują na wszelkie sposoby, to poza szczególnymi układami prywatnych kosztów i korzyści, należy spodziewać się właśnie równowag Nasha, przedsiębiorczości w poszukiwaniu zysków, a nie produktywności, uchylania się od składki na dobro publiczne itp. Zgodnie z konstytuującą główny nurt ekonomii logiką wyjaśniania sytuacyjnego, wybierany jest po prostu taki rodzaj działalności, po którym można oczekiwać największej nadwyżki korzyści nad kosztami, bez względu na „produktywność” lub „koszty społeczne”. Zamiast więc przyjmowania założeń ad hoc służących wygodnej analizie nadmiernie abstrakcyjnych modeli, należałoby zgodnie $\mathrm{z}$ istotą podejścia ekonomicznego zidentyfikować $\mathrm{w}$ kategoriach kosztów i korzyści te szczególne sytuacje, w których podmioty decydują się przestrzegać zasad tworzących efektywne rynki i państwa.

\section{RELACJE PRZYCZYNOWE I SYSTEMOWE PAŃSTWA I RYNKU - ISTOTA PROBLEMU}

Już Adam Smith zauważył, że z podziału pracy wynikają korzyści społeczne, związane $z$ efektami skali i specjalizacji. Jednak wraz ze wzrostem zaawansowania podziału pracy, wzrasta liczba wymian pomiędzy coraz mniej społecznie powiązanymi ze sobą ludźmi, a podział jednego procesu produkcyjnego pomiędzy różne podmioty powoduje wzrost specyficzności przedmiotu wymiany. Rosną zatem koszty transakcyjne w skali gospodarki. W warunkach realnej możliwości zdobycia dóbr drogą przemocy, a także przy niedoskonałej wiedzy i oportunizmie podmiotów, subiektywnie ekwiwalentna wymiana rynkowa jest pewnym rodzajem kooperacji. Wiadomo przy tym z teorii gier, że kooperacja pomiędzy maksymalizującymi jednostkami jest tym bardziej prawdopodobna, im więcej razy gra jest powtarzana, im bardziej pełna jest informacja o graczach i im mniejsza jest ich liczba ${ }^{13}$. Ludzie są skłonni do kooperacji pod warunkiem takiego zobowiązania obu stron do dotrzymania warunków umowy, które byłoby wiarygodne, tj. oparte na przekonaniu, że w danej sytuacji w interesie partnera jest raczej dotrzymać zobowiązania niż je zerwać ${ }^{14}$. W społecznościach lokalnych wymiana jest powtarza-

\footnotetext{
${ }^{13}$ D. C. North, Institutions, Institutional Change..., rozdział 2: Cooperation: the theoretical problem.
}

${ }^{14}$ A. Greif, Commitment, Coercion and Markets: The Nature and Dynamics of Institutions Sup- 
na w ramach niewielkiej grupy dobrze znających się podmiotów, a wiarygodność zobowiązań (credible commitment) zapewniają mechanizmy kontroli społecznej. Tymczasem środowisko neoklasycznego rynku stanowi dokładną antytezę warunków sprzyjających kooperacji: interakcje pomiędzy anonimowymi i niepowiązanymi więzami społecznymi uczestnikami wymiany rynkowej są incydentalne, nawet jednorazowe. Jak zatem wymiana na rynkach w gospodarce o zaawansowanej specjalizacji i podziale pracy jest w ogóle możliwa? ${ }^{15}$

North i Greif na to pytanie odpowiadają zgodnie: wiarygodność zobowiązań jest możliwa dzięki instytucjom. North definiuje instytucje jako „wytworzone przez ludzi ograniczenia, które kształtują strukturę ludzkich interakcji”. Ich oddziaływanie polega na tym, że wprowadzając dodatkowe selektywne bodźce do rachunków kosztów i korzyści jednostek, kanalizują wybory w konkretnym kierunku. Jeżeli zakres podziału pracy jest ograniczony wielkością rynku, to z kolei wielkość rynku jest ograniczona zasobem i jakością instytucji umożliwiających egzekwowanie kontraktów (contract-enforcement institutions) ${ }^{16}$. Efektywne instytucje - wyjaśnia North - podnoszą korzyści z kooperacji i koszty oszustwa, zmniejszają natomiast koszty transakcyjne i umożliwiają w ten sposób realizację korzyści z wymiany ${ }^{17}$. Skąd jednak z kolei biorą się tego rodzaju instytucje?

Również w zgodnej opinii Northa i Greifa, instytucje nieformalne, w których realizacja sankcji należy do partnera wymiany (secondo-party enforcement) lub lokalnej społeczności, mają ograniczony zasięg pod względem możliwej liczby osób uczestniczących w wymianie. Dlatego nie są w stanie zapewnić warunków niezbędnych do funkcjonowania rynków o masowości, stopniu specjalizacji i konkurencyjności zbliżonych do rynków modelowanych przez neoklasyczną ekonomię i składających się na współczesną gospodarkę. Do zdefiniowania i egzekwowania instytucji takich rynków konieczne zdaniem omawianych autorów jest państwo. Mówić można o pewnych transakcyjnych dobrach publicznych (takich jak kodyfikacja praw własności i instytucji rynku czy bezstronne egzekwowanie prawa zobowiązań przez trzecią stronę - third-party contract enforcement - na wielkich, zróżnicowanych kulturowo obszarach), których - teoretycznie i faktograficznie rzecz biorąc - dostarczyć może jedynie rozwinięty aparat państwowy. Douglass C. North wyśledził właśnie w dziejach Europy Zachodniej, jak na skutek zmian w technologii wojskowej, demografii i systemach finansów publicznych wykształciły się względnie efektywne państwa, wiarygodnie dostarczające transakcyjnych

porting Exchange, [w:] Handbook of New Institutional Economics, red. C. Menard, M. Shirley, Springer, Dordrecht 2005, s. 730.

${ }^{15}$ D. C. North, Institutions, Institutional Change..., s. 12.

${ }^{16}$ Ibidem.

${ }^{17}$ D. C. North, Institutions, „Journal of Economic Perspectives” 1991, vol. 5, no. 1, s. 98. 
dóbr publicznych, umożliwiając w ten sposób powstanie względnie efektywnych rynków, nowoczesnej gospodarki rynkowej i „,́́wiata Zachodu” w ogóle.

Jeżeli efektywny rynek jako warunku wstępnego potrzebuje efektywnego państwa, które ustanowiłoby i egzekwowało instytucje rynku, to konsekwencje tej konstatacji dla teoretyków ekonomii wydają się daleko idące. Po pierwsze, rzeczywistość historyczna wydaje się dokładnie odwrotna, niż zakłada „neoklasyczna fikcja” - najpierw musi istnieć państwo, a rynki jedynie są przez nie „organizowane”. Skoro zakładana „natura ludzka” uczestników rynku nie wzbudza wśród ekonomistów kontrowersji, to można nawet pokusić się o stwierdzenie, że błędy rynku - rozumiane najszerzej jako wybory ich uczestników niezgodne z oczekiwaniami czy interesem społecznym - w całości wynikają z błędów instytucji (institutional failure), a więc z błędów państwa. Albo, innymi słowy, że nie ma błędów rynku - są tylko błędy państwa, które zawiodło w dostarczeniu danemu rynkowi niezbędnych do „prawidłowego” funkcjonowania instytucji. Świadomość taka wydaje się towarzyszyć ekonomistom zawodowo lub doraźnie zajmującym się rynkami o łatwo dostrzegalnej roli instytucjonalnej państwa, takimi jak rynki finansowe. Dla przykładu, prof. Leszek Balcerowicz stwierdził w kontekście kryzysu finansowego w Stanach Zjednoczonych, że przecież rynki finansowe nie działają w próżni, że ramy ich funkcjonowania tworzą władze publiczne i że „jeśli ramy są wadliwe, działalność rynków finansowych nie może być prawidłowa”" ${ }^{18}$. North i Greif wydają się argumentować, że po prostu dokładnie to samo można powiedzieć o każdym innym rynku.

Zupełnie nieuzasadniony byłby jednak wniosek, iż rynek jest mechanizmem kruchym i zawodnym w przeciwieństwie do państwa. Państwo bowiem traktowane bywa przez teorię ekonomii podobnie wysoce abstrakcyjnie jak rynki. Zwykle w ekonomii abstrahuje się od organizacji egzekwowania instytucji, traktując ją jak pojedynczy byt i skupiając się na jego relacji z resztą społeczeństwa. Za M.Weberem przyjmuje się definicję państwa jako organizacji posiadającej legalny monopol na używanie przemocy, a następnie modeluje jako maksymalizującego przychód monarchę, bandytę lub „reprezentatywnego agenta” obywateli. North twierdzi, że „przez przymknięcie oczu na fakt, że państwo jest organizacją, podejście to nie dostrzega, jak wewnętrzna dynamika relacji między elitami koalicji dominującej wpływa na interakcję państwa ze społeczeństwem"19. Nie jest znów uznawane za istotne zagadnienie, jak konkretnie pewna grupa społeczna uzyskała legalny monopol na przemoc i do czego właściwie używa go zgodnie z logiką maksymalizacji prywatnych korzyści. Podobnie jak w przypadku efektywnych rynków, punktem odniesienia przez długi czas było efektywne państwo, regulu-

${ }^{18}$ Za: K. Tracz, Chrześcijanin kontra kryzys, „Tygodnik Powszechny”, 20.09.2009, nr 38, s. 22.

${ }^{19}$ D. C. North, J. J. Wallis, B. R. Weingast, Violence and Social Orders. A Conceptual Framework for Interpreting Recorded Human History, Cambridge University Press, Cambridge 2009, s. 17. 
jące gospodarkę w celu maksymalizacji korzyści społecznych. Tymczasem - jak zauważa North „instytucje niekoniecznie, a nawet rzadko, tworzone są, by były społecznie efektywne; raczej przynajmniej instytucje formalne tworzone są, by służyć interesom tych, którzy mają wystarczającą siłę przetargową, by konstruować nowe zasady”20. Jak zwrócił uwagę Avner Greif, „rozwój wymiany rynkowej zależy od dwóch filarów instytucjonalnych [...] - rynki potrzebują także instytucji, które powstrzymają sam aparat państwowy przed naruszaniem praw własności”21. Innymi słowy, potrzebne są instytucje ograniczające przemoc (coercion-constraining institutions), aby zapewnić wiarygodne zobowiązania ze strony władców i funkcjonariuszy państwa. A zatem znów efektywność państwa - rozumiana jako dbałość skrajnie prywatnie-interesownych jednostek o interes społeczny - domaga się ekonomicznego wyjaśnienia. Konkretnie odpowiedzieć należy na pytania, w jakich okolicznościach instytucjonalnych decydentom państwowym opłaca się tworzenie instytucji sprzyjających dobremu funkcjonowaniu rynków oraz w jakich warunkach historycznych takie okoliczności instytucjonalne powstają i w dalszej perspektywie - jak je osiągnąć.

Za przykład zastosowania powyższych koncepcji do wyjaśnienia procesów zawodności rynku i państwa niech posłuży Northowskie wyjaśnienie obserwowanego od XIX wieku wzrostu udziału wydatków publicznych w dochodzie narodowym w gospodarce rynkowej, czyli wyjaśnienie prawa Wagnera ${ }^{22}$. Jak wspomniano również wyżej, przedsiębiorcy mają do wyboru wiele możliwości poszukiwania zysków. Jak stwierdził Baumol, podmiot może wybrać produktywną przedsiębiorczość Schumpeterowską, ale również przedsiębiorczość nieproduktywną, w zależności od „zasad gry, które określają relatywne opłacalności poszczególnych rodzajów przedsiębiorczości”23. Po prostu Baumol przyjmuje, że osoby „wybierają działania relatywnie wyżej nagradzane w ramach danych reguł instytucjonalnych"24. Organizacje mogą następnie korzystać z rozmaitych sposobów nieproduktywnego poszukiwania zysków, usystematyzowanych przez Bhagwatiego ${ }^{25}$. W ujęciu Northa: „ramy instytucjonalne dyktują możliwości maksymalizacyjne organizacji” ${ }^{26}$. W kontekście wzrostu państwa i udziału wydatków publicznych w PKB, North dostrzega zasługi teorii wyboru publicznego, jednak uważa je za

${ }^{20}$ D. C. North, Institutions, Institutional Change..., s. 16.

${ }^{21}$ A. Greif, Commitment, Coercion..., s. 727.

${ }^{22}$ Por. S. Owsiak, Finanse publiczne, Wydawnictwo Naukowe PWN, Warszawa 2004, s. 44.

${ }^{23}$ W. J. Baumol, Entrepreneurship: Productive, Unproductive, and Destructive, "Journal of Political Economy” 1990, vol. 98, no. 5, s. 899.

${ }^{24} \mathrm{~B}$. Klimczak, Model cztowieka gospodarującego-szansa czy zagrożenie dla uczciwego biznesu?, [w:] B. Klimczak, Między ekonomiq a etyka, Wyd. UE we Wrocławiu, Wrocław 2008, s. 22.

${ }^{25}$ Zob. J. N. Bhagwati, Directly Unproductive, Profit-Seeking (DUP) Activities, ,Journal of Political Economy" 1982, vol. 90, no. 5, s. 988-1002.

${ }^{26}$ D. C. North, Institutions, Institutional Change..., s. 78. 
niewystarczające do odpowiedzi na pytanie, które można sformułować następująco: Skoro preferencje i „natura ludzka” nie zmieniły się, z jakich powodów poszukiwanie renty przy pomocy państwa odgrywa od drugiej połowy XIX wieku coraz większą rolę? North oferuje odpowiedź dotyczącą warunków amerykańskich zgodną z zarysowaną wcześniej logiką: zmianie ulec musiała struktura kosztów/ korzyści alternatywnych sposobów poszukiwania zysków. Po pierwsze, potencjalne korzyści korzystania z mechanizmów politycznych względem przedsiębiorczości Schumpeterowskiej wzrosły. Jak wspomniano wyżej, wzrost stopnia specjalizacji i podziału pracy prowadzi do wzrostu popytu na „usługi obsługi transakcyjnej” redukującej koszty transakcyjne ${ }^{27}$. Coraz większe obszary gospodarki dostają się pod kontrolę prawną i administracyjną państwa, co sprawia, że korzyści z dostępu do tej kontroli rosną. I po drugie, koszty korzystania z mechanizmów politycznych relatywnie spadły względem mechanizmu rynkowego. W Stanach Zjednoczonych spowodowane to było zmianami instytucjonalnymi ułatwiającymi podnoszenie podatków i przejmowanie przez państwo funkcji redystrybucyjnych oraz przesuwanie istotnych kompetencji gospodarczych $\mathrm{z}$ ciał ustawodawczych do specjalnie powoływanych komisji Kongresu i agencji rządowych ${ }^{28}$.

Jeżeli efektywność rynków zależy od efektywności państwa, to od czego zależy efektywność państwa? W miarę cofania się w budowanym przez siebie łańcuchu przyczynowym, North staje się coraz bardziej niepewny i enigmatyczny w sformułowaniach. Tradycyjna teoria wyboru publicznego - pisze - czyni z państwa niewiele więcej niż coś na kształt mafii czy Lewiatana - maszynerię do redystrybucji bogactwa i dochodu. Jednak jest to jego zdaniem tylko część prawdy o funkcjonowaniu wielu państw. Aby wyjaśnić powstawanie i egzekwowanie efektywnych instytucji formalnych, „musimy wiedzieć znacznie więcej o normach zachowań pochodzących z kultury"29. Wątek ten nieco tylko bardziej dogłębnie rozwija Greif. Odwołując się do zjawiska path dependence, wskazuje on np. różnice w przekonaniach pomiędzy kulturami „indywidualistycznymi” i „kolektywistycznymi” jako przyczyny rozbieżności historii społeczno-politycznej krajów basenu Morza Śródziemnego ${ }^{30}$. Z kolei można by jednak zadać pytanie, skąd biorą się przekonania kulturowe danej społeczności. Tutaj North wyraźnie przyznaje, że przekracza to naszą dzisiejszą wiedzę. $Z$ jednej strony - pisze - argumentować można, że specyficzna struktura przekonań religijnych chrześcijaństwa w długim

${ }^{27}$ D. C. North, J. J. Wallis, American Government Expenditures: A Historical Perspective, „American Economic Review” 1982, vol. 72, no. 2, s. 336.

${ }^{28}$ D. C. North, Structure and Change..., s. 193.

${ }^{29}$ Idem, Institutions, Institutional Change..., s. 140.

${ }^{30}$ A. Greif, Cultural Beliefs and the Organization of Society: A Historical and Theoretical Reflection on Collectivist and Individualist Societies, "Journal of Political Economy” 1994, vol. 102, no. 5, s. 912-950. 
okresie sprzyjała wzrostowi gospodarczemu i wolnościom obywatelskim. „Jednak to szczególne warunki instytucjonalne części średniowiecznej Europy zapewniły ten rodzaj doświadczeń kulturowych, które posłużyły za katalizator" takiego rozwoju. Oddziaływania w obie strony były zapewne każde na swój sposób „częścią opowieści” (oryg. part of the story) o roli kultury w powstaniu „świata Zachodu”, której spisanie należy jednak do raczej odległej przyszłości ${ }^{31}$.

\section{ZAKOŃCZENIE}

Jak starano się wykazać, Douglass C. North oraz Avner Greif mają wiele do zaoferowania teoretykom ekonomii w zakresie zawodności rynków i państwa. Poprzez konsekwentne trzymanie się podstaw neoklasycznej ekonomii i teorii gier otrzymują oni wyniki nieoczywiste z punktu widzenia standardowych teorii oraz wprowadzają do omawianych zjawisk aspekt instytucjonalny w wymiarze historycznym - niezbędnym do zrozumienia genezy oraz projektowania systemów instytucjonalnych. W przeciwieństwie do standardowych ujęć ekonomicznych, z historyczno-instytucjonalnego punktu widzenia to efektywność rynków i państwa należałoby traktować jako domagające się wyjaśnień „odchylenia” od normy, a „zawodności” - jak stan wyjściowy analiz. Prawdziwe rynki i państwa nie przypominają modeli - nie są abstrakcyjnymi mechanizmami, które generalnie działają, „chyba że” lub „dopóki nie” wystąpią „niedoskonałości”. Odwrotnie: to efektywność osiągana jest w wyjątkowych warunkach i to one właśnie zasługują na uwagę i wyjaśnienie, bo systematycznej wiedzy na ich temat wciąż brak. Heterodoksyjna literatura ekonomiczna oraz innych nauk społecznych, owszem, pełna jest haseł w rodzaju: przeszłość i kultura „mają znaczenie” ${ }^{2}$. Jednak potrzebne są, podobne do budowanego przez Northa i Greifa, hipotetyczne łańcuchy oddziaływań (rynki organizowane są przez państwo, które działa jako odzwierciedlenie struktury grup interesów i kultury, które z kolei wynikają z zależnej od ścieżki historii społeczeństwa) - spójne logicznie próby włączenia w ortodoksyjną ekonomię niesłusznie (jak jest to coraz bardziej jasne) pominiętych aspektów społeczno-kulturowych gospodarowania.

Przedstawiony punkt widzenia nie jest oczywiście pozbawiony istotnych słabości. Rozważania omawianych autorów ze względu na rezygnację $\mathrm{z}$ wielu neoklasycznych założeń upraszczających uwikłane są w analizy wysoce skomplikowanych procesów społeczno-politycznych i gospodarczych. Pomimo deklaracji

${ }^{31}$ D. C. North, Understanding the Process of Economic Change, Princeton University Press, Princeton 2005, s. 135-137.

${ }^{32}$ Por. Kultura ma znaczenie, red. L. E. Harrison, S. P. Huntington, Zysk i S-ka, Poznań 2003. 
przywiązania do empirycznej sprawdzalności teorii, autorzy ci właściwie w ogóle nie podejmują się operacjonalizacji używanych pojęć oraz ich pomiaru, z jednym ważnym wyjątkiem - znanego badania Northa i Wallisa, którego celem był pomiar dynamiki kosztów transakcyjnych w gospodarce amerykańskiej ${ }^{33}$. W rezultacie omawiane prace pozostają przekonująco uzasadnionymi i ukierunkowanymi teoretycznie, ale jednak - propozycjami myślowymi, analitycznymi konstrukcjami i schematami pojęciowymi (conceptual framerworks), a ich konkretyzacja, operacjonalizacja i empiryczne sprawdzenie - pozostawione są następcom. Deklaracja z przedmowy do Violence and Social Orders dobrze oddaje sposób myślenia autorów: „Nie przedstawiamy formalnego modelu, który generuje testy empiryczne lub predykcje. W zamian, proponujemy schemat pojęciowy, który uwzględnia wyraźnie endogeniczne wzorce zachowań społecznych, gospodarczych, politycznych, wojskowych, religijnych i edukacyjnych" ${ }^{34}$. Przy pewnej życzliwości można zrozumieć ograniczenie się do łatwiejszego etapu pracy do wykonania, ale przecież celem autorów była teoria, za pomocą której możliwe byłoby formułowanie zaleceń dla praktyków. W pracach Northa ma się dodatkowo wrażenie pewnej nadmiernie, względem możliwości, rozbudowanej ambicji poznawczej i fatalizmu - zrozumiałych u historyka, ale jednak zaskakujących z punktu widzenia celów autora. Brak na przykład wskazówek, czy i jakie są szanse zmiany niekorzystnej ścieżki rozwoju historyczno-kulturowego, na czym taka zmiana miałaby polegać, kto i w jaki sposób miałby ją przeprowadzić. A przecież są to kluczowe kwestie dla budowy efektywnych rynków i państwa w wielu krajach świata.

$Z$ łatwością można jednak wymienić również korzyści poznawcze wynikające $z$ omawianych prac. Być może nie na skalę zapowiadaną przez samych autorów, ale spostrzeżenia Northa i Greifa już dziś wydają się rzeczywiście mieć ważne implikacje praktyczne zarówno dla współczesnych przedsięwzięć projektowania instytucji, jak i dla nauki, a nawet dydaktyki, ekonomii.

Zacząć wypada właśnie od niezwykle istotnego aspektu dydaktycznego. Ze względu na niewielką liczbę godzin przeznaczonych w Polsce na teorię ekonomii, nawet na kierunku ekonomia, student zapoznaje się jedynie z najbardziej uproszczonymi formami neoklasycznego myślenia o rynkach i państwie, a zatem tymi zagrożonymi wrażeniem ich „domyślnej” efektywności. Doskonale konkurencyjny rynek, nad którym wisi „zagrożenie” zaburzenia mechanizmu rynkowego przez państwo, zdominował czasowo i merytorycznie nauczanie o funkcjonowaniu rynków w ogóle. Mniej uważni studenci mogą odnieść wrażenie, że gospodarka składa się w głównej mierze właśnie z rynków doskonale konkurencyjnych,

${ }^{33}$ J. J. Wallis, D. C. North, Measuring the Transaction Sector in the American Economy, [w:] Long-term Factors in American Economic Growth, red. S. L. Engerman, R. E. Gallman, University of Chicago Press, Chicago 1986, s. 95-148.

${ }^{34}$ D. C. North, J. J. Wallis, B. R. Weingast, Violence and Social Orders..., s. xii. 
a zawodności rynku występują w życiu gospodarczym incydentalnie, co wydaje się też wynikać z niektórych podręczników akademickich, sugerujących, że działanie „niewidzialnej ręki” jest immanentną cechą konkurencyjnych rynków i może być jedynie „zakłócane”, ,jeżeli” (!) wystąpią „ułomności” ${ }^{35}$. Druga możliwa skrajność polega oczywiście na nadmiernym zaufaniu do państwa jako do abstrakcyjnego bytu, który altruistycznie maksymalizuje funkcję dobrobytu społecznego. Urząd państwowy w postaci Ministerstwa Nauki i Szkolnictwa Wyższego wciąż wymaga od absolwentów studiów ekonomicznych i prawniczych najwyżej podstawowej teoretycznej wiedzy o „nieefektywnościach” rynku i państwa, a nie zastosowań współczesnej ekonomii instytucjonalnej do zjawisk, które ukształtowały i wciąż kształtują rzeczywistość gospodarczą naszego kraju.

Tymczasem koncepcje i schematy pojęciowe proponowane przez Northa i Greifa oferują spojrzenie na problem relacji rynków i państwa w sposób użytecznie odideologizowany. Podkreślenie interesu własnego w projektowaniu procesów ekonomicznych i politycznych doprowadziło do wielokrotnie wyrażanej przez Northa konkluzji, że ani „niewidzialna ręka” rynku, ani „widzialna ręka” rządu nie wykazują żadnej teleologii postępu, ani nie gwarantują w sposób automatyczny społecznych korzyści, co wskazuje na bezzasadność jakiegokolwiek dogmatycznego zaufania do rynku albo państwa. North zwraca również uwagę, że problem „ile państwa w gospodarce” jest dramatycznie źle sformułowany, a prowadzenie dyskusji po tej linii rozumowania stanowi w istocie element gry gospodarczych i politycznych grup interesu w kontekście konkretnego przedsięwzięcia regulacyjnego. Reformy przeprowadzane pod hasłami państwa „taniego” bądź „minimalnego" mogą prowadzić do uchylania się państwa od jego funkcji instytucjonalnej w gospodarce, a zatem - pozornie paradoksalnie - do powstawania i pogłębiania zawodności rynków.

Szczególnie ważne wydają się tego rodzaju wnioski dla krajów przechodzących transformację ustrojową z gospodarki centralnie planowanej oraz zwłaszcza dla krajów Trzeciego Świata. Kraje te przez dziesięciolecia swej niepodległości padały zarówno ofiarą ideologii socjalistycznej i posługującego się nią państwa typu „drapieżnego” (predatory state), jak i ideologii neoliberalnej, z której wydaje się wynikać, że „im mniej państwa w gospodarce, tym lepiej”. Dziś w wielu krajach Ameryki Łacińskiej i Afryki korelacja między nędzą gospodarczą i niedorozwojem publicznych zadań państwa wydaje się łatwo dostrzegalnym faktem. Omówione koncepcje teoretyczne ułatwiają sformułowanie problemu krajów rozwijających się w kategoriach trudnego zadania budowy struktury instytucji państwa wiarygodnej $\mathrm{w}$ relacjach $\mathrm{z}$ obywatelami, która umożliwiłaby wiarygodne zobo-

${ }^{35}$ P. A. Samuelson, W. D. Nordhaus, Ekonomia, t. 1, Wydawnictwo Naukowe PWN, Warszawa 2006, s. 63-64. 
wiązania $\mathrm{w}$ relacjach rynkowych. Historycznie zorientowana ekonomia instytucjonalna może dać pewne - dzisiaj jeszcze dość abstrakcyjne - wskazówki w tym zakresie. Zgodnie z logiką ekonomicznej teorii instytucji, zmian ustroju na w miarę efektywny rynkowy i demokratyczny można będzie spodziewać się w krajach Trzeciego Świata tylko wówczas, gdy obecnie dominującym tam grupom interesu taka zmiana będzie się prywatnie opłacać. Grupy interesu wybierają bowiem produktywne innowacje instytucjonalne tylko wtedy, gdy każda inna możliwość będzie się charakteryzować gorszą relacją korzyści i kosztów. Stąd należy zalecać działania zwiększające relatywną opłacalność produktywnej przedsiębiorczości: $z$ jednej strony przez stanowienie i poprawę egzekwowania instytucji zmniejszających koszty i zwiększających korzyści korzystania z rynku, z drugiej - poprzez reformy instytucjonalne zwiększające koszty i zmniejszające korzyści korzystania z nieproduktywnych sposobów poszukiwania zysków, np. oddziaływań na agendy rządowe i komisje ustawodawcze.

Zasługą Douglassa C. Northa i Avnera Greifa jest przede wszystkim ugruntowane teoretycznie zwrócenie uwagi na tę problematykę, wyjęcie jej z abstrakcyjnych i łatwo ideologizowanych rozważań statycznych i pozbawionych realistycznego kontekstu instytucjonalnego. Znaczną większość pracy empirycznej pozostawili oni co prawda do wykonania kolejnym pokoleniom badaczy, jednak wielkie syntezy nowej ekonomii instytucjonalnej - które tworzy zwłaszcza North - dają uzasadnioną nadzieję, że w nieodległej przyszłości więcej będziemy rozumieć i umieć w zakresie przeciwdziałania zawodnościom rynku i państwa.

\section{MARKET AND GOVERNMENT FAILURES IN HISTORICAL INSTITUTIONAL ANALYSIS BY DOUGLASS C. NORTH AND AVNER GREIF}

SUMMARY

Economic historians Douglass C. North and Avner Greif use the tools on the New Institutional Economics and Game Theory and draw the attention of economists to the fact that both markets and governments are institutional constructs created by opportunistic individuals and groups with different interests. They show how exceptionally many are the social and cultural conditions of credible commitment which are necessary for the emergence of efficient markets and government. In contrast with standard economic approaches, from the historical-institutional point of view it is the efficiency of some markets and governments which should be treated as "deviations" from a norm and states of "failure" - as a starting points in analyses of markets and governments. This observation bears important implications both for contemporary institutional engineering and for economic theory, and even for teaching economics. 
